\title{
Treatment of slaughterhouse wastewater with iron electrodes
}

\author{
Ü. Tezcan Ün ${ }^{1}$, A. S. Koparal ${ }^{2}$ \& Ü. Bakir Öğütveren ${ }^{2}$ \\ ${ }^{I}$ Anadolu University, Faculty of Engineering and Architecture, \\ Department of Environmental Engineering, Eskisehir, Turkey \\ ${ }^{2}$ Applied Research Center for Environmental Problems, Anadolu \\ University, 26470, Eskisehir, Turkey
}

\begin{abstract}
This study is mainly focused on the electrocoagulation treatment of slaughterhouse wastewater for determining effects of the basic operating parameters such as current density, and supporting electrolyte dosage using iron electrodes. The performance of the cylindrical electrochemical reactor was evaluated in batch experiments. While one pole of the power supply was connecting to the reactor as an anode, the other was connected to a stirrer for operation as a cathode. Experiments were carried out by introducing the cattle slaughterhouse wastewater into the reactor and applying a certain amount of current to the circuit. The removal efficiency of the COD increased with increasing current density. The removal efficiencies of $51.3 \%, 53.8 \%, 59.9 \%$ and $61.2 \%$ were obtained for the current densities of $5,10,15,20 \mathrm{~mA} / \mathrm{cm}^{2}$ with the energy consumptions of $15,48,91$ and $168 \mathrm{kWh} / \mathrm{m}^{3}$ respectively. However increasing the $\mathrm{Na}_{2} \mathrm{SO}_{4}$ dosage, which was added as a supporting electrolyte, from 0.1 to $0.2 \mathrm{M}$ has an adverse effect on COD removal. It can be concluded from this study that treatment of slaughterhouse wastewater can be achieved by applying electrocoagulation.

Keywords: electrocoagulation, COD, slaughterhouse wastewater, iron electrode, organic matter.
\end{abstract}

\section{Introduction}

The slaughterhouse industry is a very old human activity and, although it is still a relatively small-scale industrial sector, its environmental impact has grown 
considerably due to the increase in plant production [1]. Slaughterhouses and meat processing plants generate a large volume of effluents. The composition of water per slaughtered animal varies according to the animal and the process employed in each industry, Slaughterhouse wastewaters are considered by the different European legislations as very contaminating due to their composition, characterized mainly by a complex mixture of fats, proteins and fibers. The organic matter concentration is medium to high and the residues are partially solubilized, leading to a highly contaminating effect in riverbeds or sewer systems if the wastewater is not previously treated.

In recent years, electrochemical methods such as electrooxidation [2, 3] and electrocoagulation [4] have been successfully tested to treat various industrial pollutants. Removal of organic matter from wastewaters by electrocoagulation has been achieved with high removal efficiencies [5, 6]. Electrocoagulation (EC) process generated numerous flocs, which permitted to attain high removal efficiency from wastewater. EC is a process consisting of creating a floc of metallic hydroxides within the effluent to be cleaned, by electrodissolution of soluble anodes. Iron and aluminum are generally used as sacrificial anodes.

The Fe (II) ions are the common ions generated by the dissolution of iron. In contrast, $\mathrm{OH}^{-}$ions are produced at the cathode. By mixing the solution, hydroxide species are produced which cause the removal of matrices by adsorption and coprecipitation. In the study of iron anodes, two mechanisms for the production of the metal hydroxides have been proposed [7].

Mechanism 1:

Anode:

$$
\begin{gathered}
4 \mathrm{Fe}_{(\mathrm{s})} \rightarrow 4 \mathrm{Fe}_{(\mathrm{aq})}^{2+}+8 \mathrm{e}^{-} \\
4 \mathrm{Fe}_{(\mathrm{aq})}^{2+}+10 \mathrm{H}_{2} \mathrm{O}_{(\mathrm{l})}+\mathrm{O}_{2(\mathrm{aq})} \rightarrow 4 \mathrm{Fe}(\mathrm{OH})_{3(\mathrm{~s})}+8 \mathrm{H}_{(\mathrm{aq})}^{+}
\end{gathered}
$$

Cathode:

$$
8 \mathrm{H}_{(\mathrm{aq})}^{+}+8 \mathrm{e}^{-} \rightarrow 4 \mathrm{H}_{2(\mathrm{~g})}
$$

Overall:

$$
4 \mathrm{Fe}_{(\mathrm{S})}+10 \mathrm{H}_{2} \mathrm{O}_{(\mathrm{l})}+\mathrm{O}_{2(\mathrm{aq})} \rightarrow 4 \mathrm{Fe}(\mathrm{OH})_{3(\mathrm{~s})}+4 \mathrm{H}_{2(\mathrm{~g})}
$$

Mechanism 2:

Anode:

$$
\begin{gathered}
\mathrm{Fe}_{(\mathrm{s})} \rightarrow \mathrm{Fe}_{(\mathrm{aq})}^{2+}+2 \mathrm{e}^{-} \\
\mathrm{Fe}_{(\mathrm{aq})}^{2+}+2 \mathrm{OH}_{(\mathrm{aq})}^{-} \rightarrow \mathrm{Fe}(\mathrm{OH})_{2(\mathrm{~s})}
\end{gathered}
$$

Cathode:

$$
2 \mathrm{H}_{2} \mathrm{O}_{(\mathrm{l})}+2 \mathrm{e}^{-} \rightarrow \mathrm{H}_{2(\mathrm{~g})}+2 \mathrm{OH}_{(\mathrm{aq})}^{-}
$$

Overall:

$$
\mathrm{Fe}_{(\mathrm{s})}+2 \mathrm{H}_{2} \mathrm{O}_{(\mathrm{l})} \rightarrow \mathrm{Fe}(\mathrm{OH})_{2(\mathrm{~s})}+\mathrm{H}_{2(\mathrm{~g})}
$$

The $\mathrm{Fe}(\mathrm{OH})_{\mathrm{n}(\mathrm{s})}$ formed remains in the aqueous stream as a gelatinous suspension, which can remove the pollutants from wastewater either by complexation or by electrostatic attraction followed by coagulation. 
A limited number of reports in the literature are available on the electrochemical treatment of the slaughterhouse wastewater. The electrocoagulation of poultry slaugherhouse wastewater using four parallel monopolar aluminum and iron electrodes was studied at a Plexiglas reactor by Kobya et al. [8]. Electrolysis of fowl slaughterhouse wastewater in order to minimize odors and organic matter was studied using cast iron electrodes by Marconato et al. [9].

The aim of this work was to evaluate the performance of electrochemical reactor using an iron sacrificial anode in the treatment of cattle slaughterhouse wastewater. The experiments carried out were designed to study the influence of the operating variables such as current density and supporting electrolyte $\left(\mathrm{Na}_{2} \mathrm{SO}_{4}\right)$ dosage on COD removal efficiency. The specific electrical energy consumptions (SEEC) were also evaluated.

\section{Experimental setup and procedures}

The experimental setup for the electrocoagulation experiments run in the batch modes is shown in Fig. 1. The experiments were carried out in an iron reaction chamber, which served as anode. The cathode consists of two blades of iron centrally located in the chamber as the mechanical stirrer (Heidolph RZR 2102). The iron anode was $10.8 \mathrm{~cm}$ in diameter and $6.6 \mathrm{~cm}$ height.

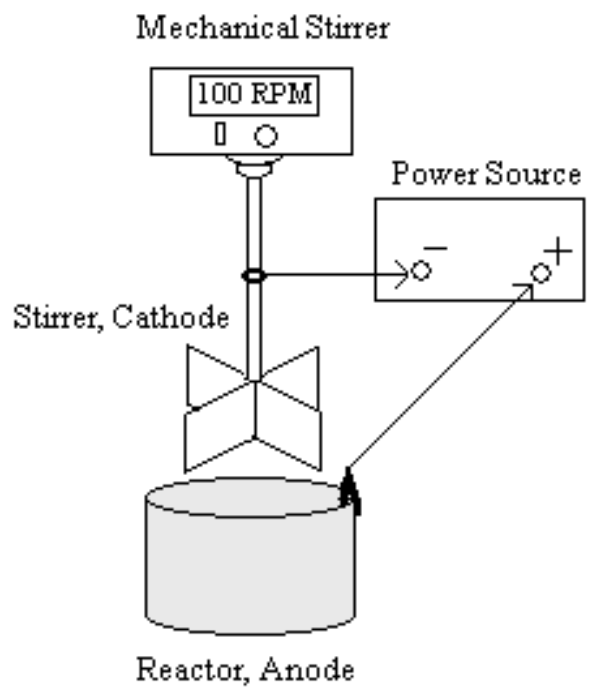

Figure 1: $\quad$ Experimental set up.

The cattle slaughterhouse wastewater used in the experiments was obtained from a factory located in Eskisehir, Turkey, and its composition is as follows: COD, $4200 \mathrm{mgL}^{-1}$; pH, 7.8; turbidity, 340 NTU. A Statron Model $3234.4 \mathrm{dc}$ Power Supply was used to apply a constant current between the anode and the 
cathode. Other instruments used in this paper are as follows: a HACH DR2000 Spectrometer for determining COD, a HACH Model 2100 P turbiditymeter, an Inolab Model (Level 1) conductimeter, an Orion Model $420 \mathrm{~A} \mathrm{pH}$ meter and a Hettich Model EBA 20 centrifuge.

Batch experiments were carried out as follows. A total of $300 \mathrm{~mL}$ of cattle slaughterhouse wastewater was first poured into the reaction chamber and then the iron cathode operated as stirrer dipped in the middle of the chamber and stirred the mixture at $100 \mathrm{rpm}$. A predetermined amount of $\mathrm{Na}_{2} \mathrm{SO}_{4}$ was added to the water. The electrocoagulation process was then initiated by applying a current. Samples from the effluent were taken at 10-min intervals, centrifuged at $5000 \mathrm{rpm}$ for $3 \mathrm{~min}$ and the supernatant liquid was measured for COD, turbidity, conductivity, and $\mathrm{pH}$.

The calculation of removal efficiency (RE\%) after electrocoagulation was performed using the formula:

$$
\mathrm{RE} \%=\left(\mathrm{C}_{\mathrm{o}}-\mathrm{C} / \mathrm{C}_{\mathrm{o}}\right) \times 100
$$

where $\mathrm{C}_{0}$ and $\mathrm{C}$ are the concentrations of $\mathrm{COD}$ before and after electrocoagulation in $\mathrm{mgL}^{-1}$, respectively.

\section{Results and discussion}

In all electrochemical processes, current density is the most important parameter for controlling the reaction rate within the reactor. It is well known that the amount of current density determines the coagulant production rate, and adjusts the rate and size of the bubble production, and hence affects the growth of flocs [10]. The effect of current density on the treatment of the slaughterhouse wastewater shown in Fig. 2(a) was investigated by varying the applied current to the wastewater at the original $\mathrm{pH}$ of the wastewater $(\mathrm{pH}: 7.8)$ and $0.1 \mathrm{M} \mathrm{Na}_{2} \mathrm{SO}_{4}$ concentration. The current density varied from 5 to $20 \mathrm{~mA} / \mathrm{cm}^{2}$ has shown a great effect on COD and turbidity removals. Raising current density causes a corresponding increase in the oxidized iron production from electrodes. The COD removal efficiencies of $51.3 \%, 53.8 \%, 59.9 \%$ and $61.2 \%$ were obtained for the current densities of $5,10,15,20 \mathrm{~mA} / \mathrm{cm}^{2}$.

For the same operating conditions, the specific electrical consumptions are also represented in Fig. 2(b). The specific electrical energy consumption (SEEC) defined as the amount of energy consumed per unit volume of treated wastewater could be determined from the following equation:

$$
\mathrm{SEEC}=\text { V.I.t } / v
$$

where SEEC is the electrical energy consumption $\left(\mathrm{kWhm}^{-3}\right), \mathrm{V}$ is the potential $(\mathrm{V}), \mathrm{I}$ is the current $(\mathrm{A}), \mathrm{t}$ is the time $(\mathrm{h}), v$ is the volume of solution $\left(\mathrm{m}^{3}\right)$.

As seen from Fig. 2(b) energy consumption increased more rapidly as the current density increases. Since applied potential have increased by increasing current density, energy consumption has also increased. Although potential and current have linearly increased, energy consumption has exponentially increased. The SEEC of $15,48,91$ and $168 \mathrm{kWh} / \mathrm{m}^{3}$ were obtained for the current densities of $5,10,15,20 \mathrm{~mA} / \mathrm{cm}^{2}$ respectively. Similar results were obtained at previous works [5]. 

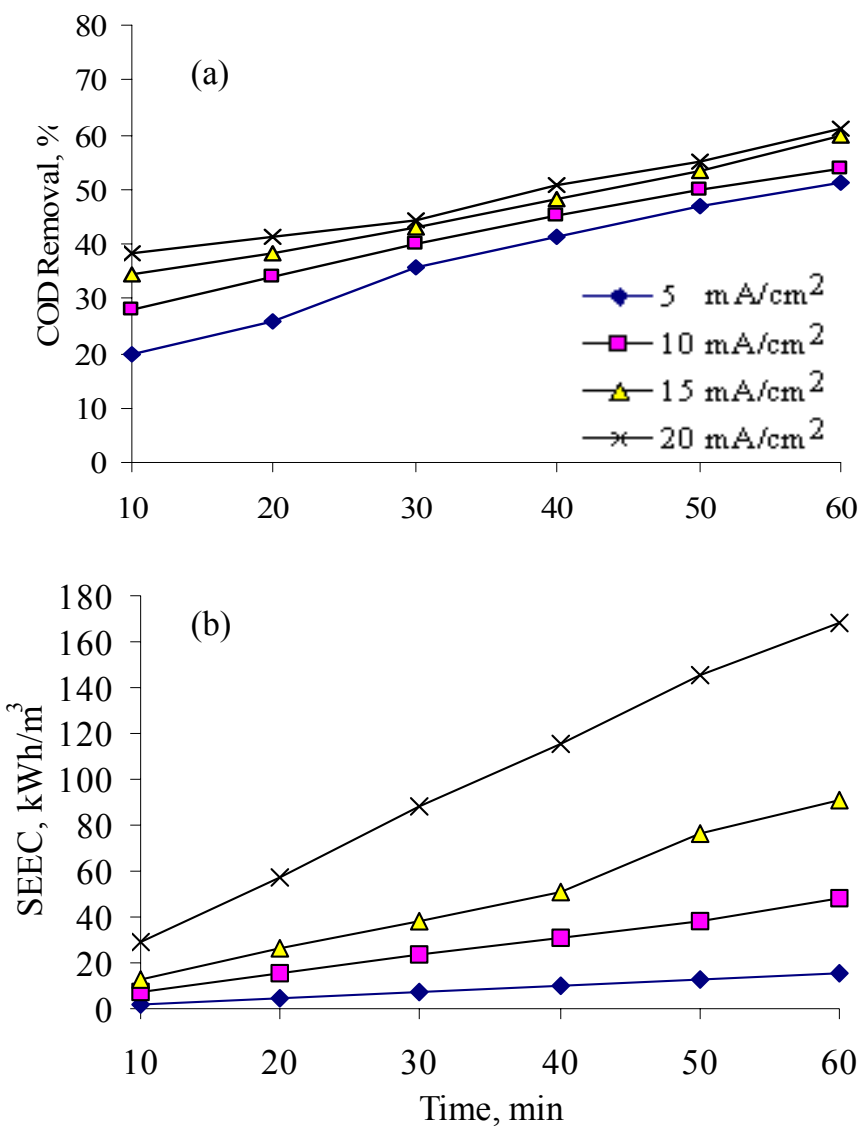

Figure 2: $\quad$ Effect of current density on COD removal (a) and SEEC (b).

Supporting electrolyte is usually employed to increase the conductivity of the water or wastewater to be treated. Solution conductivity affects the current efficiency, cell voltage and consumption of electrical energy in electrolytic cells. As a result, the conductivity of the wastewater was adjusted using $\mathrm{Na}_{2} \mathrm{SO}_{4}$ in the range of 0.1-0.2 $\mathrm{M}$. The percentage of COD removal was measured as a function of wastewater conductivity. As the $\mathrm{Na}_{2} \mathrm{SO}_{4}$ concentration increased, the conductivity of the electrolyte was enhanced correspondingly. As seen in Fig. 3(a) the percent COD removal efficiency decreased from 59.9 to $53.8 \%$ after 60 min reaction when the salt concentration was increased from $0.1 \mathrm{M}$ to $0.2 \mathrm{M}$ at the current density of $15 \mathrm{~mA} / \mathrm{cm}^{2}$. This decrease in the COD removal efficiency may be due to the fact that at high salt concentrations the excess $\mathrm{SO}_{4}{ }^{2-}$ ions interaction with the hydroxyl ions. So the excess $\mathrm{SO}_{4}{ }^{2-}$ reduces the effect of the hydroxyls ions. Furthermore, excess sulfate ions inhibit the localized corrosion of electrodes, leading to a lower COD removal efficiency. 
Increasing solution conductivity resulted in the reduction of cell voltages that caused a decrease in electrical energy consumption. Results have been shown in Fig. 3(b). The energy consumption of $91 \mathrm{kWh} / \mathrm{m}^{3}$ at $0.1 \mathrm{M} \mathrm{Na}_{2} \mathrm{SO}_{4}$ was decreased to $80.6 \mathrm{kWh} / \mathrm{m}^{3}$ with increasing $\mathrm{Na}_{2} \mathrm{SO}_{4}$ concentration to $0.2 \mathrm{M}$ while $\mathrm{COD}$ removal was decreased with increasing salt concentration. A similar effect in SEEC with an increase in conductivity was also reported by Tezcan Ün et al. [6].

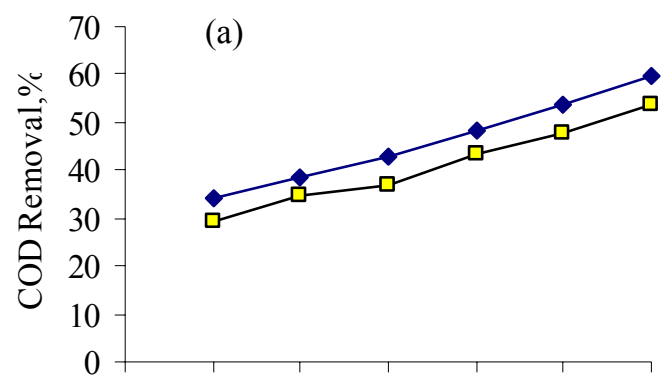

(b)

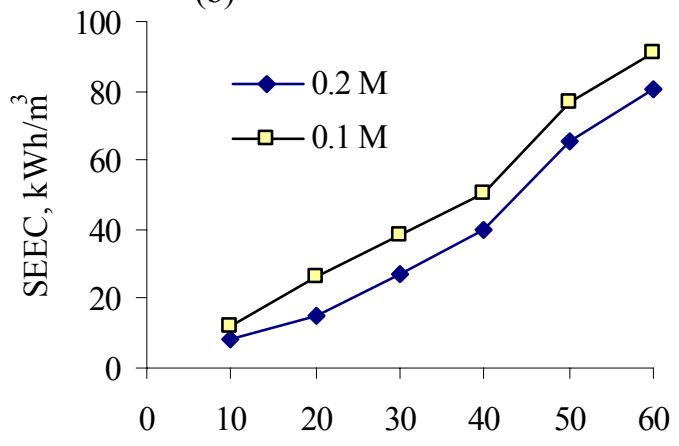

Time, $\min$

Figure 3: Effect of $\mathrm{Na}_{2} \mathrm{SO}_{4}$ concentration on $\mathrm{COD}$ removal (a) and SEEC (b).

\section{Conclusion}

Wastewater from cattle slaughterhouse has been treated using the electrocoagulation technique in the presence of added sodium sulfate. The treating of the slaughterhouse wastewater using iron sacrificial anode was affected by the current density and the amount of $\mathrm{Na}_{2} \mathrm{SO}_{4}$. According to the results obtained from the experiments, removal efficiencies have increased by increasing current density. On the other hand the energy consumptions have also increased by increasing current density. Electrocoagulation, with current density of $20 \mathrm{~mA} / \mathrm{cm}^{2}$ and operating time of $60 \mathrm{~min}$, applied to the wastewater with 
original $\mathrm{pH} 7.8$, yielded $61.2 \%$ of COD removal with the SEEC of $168 \mathrm{kWh} / \mathrm{m}^{3}$. To increase the ionic conductivity of the wastewater for minimizing energy consumption different values of $\mathrm{Na}_{2} \mathrm{SO}_{4}$ concentration were used. With the increase in conductivity, the SEEC was considerably reduced. On the contrary, it was found that higher concentration of $\mathrm{Na}_{2} \mathrm{SO}_{4}$ reduced removal of COD from the wastewater.

\section{References}

[1] Del Pozo R., Diez V. \& Beltran S., Anaerobic pre-treatment of slaughterhouse wastewater using Fixed-Film reactors. Bioresource Technolog, 71, pp. 143-149, 2000.

[2] Tezcan Ün Ü., Koparal A.S. \& Bakır Öğütveren Ü., Electrochemical desulfurization of waste gases in a batch reactor. J. Environmental Engineering (ASCE), 133(1), pp. 13-19, 2007.

[3] Tezcan Ün Ü., Altay Ü., Koparal A.S.\& Bakır Öğütveren Ü., Complete treatment of olive mill wastewaters by electrooxidation. Chemical Engineering Journal DOI:10.1016/j.cej.2007.08.009, in press.

[4] Tezcan Ün Ü., Uğur S., Koparal A.S.\& Bakır Öğütveren Ü., Electrocoagulation of olive mill wastewaters. Separation and Purification Technology 52(1), pp. 136-141, 2006.

[5] Tezcan Ün Ü., Treatment of vegetable oil refinery wastewater by electrocoagulation. Fresenius Environmental Bulletin, 16(9a), pp. 10561060, 2007.

[6] Tezcan Ün Ü., Koparal A.S. \& Bakır Öğütveren Ü., Electrocoagulation Of Vegetable Oil Refinery Wastewater Using Aluminum Electrodes. Journal Of Environmental Management, DOI:10.1016/j.jenvman.2007.11.007, in press.

[7] Şengil I. A., Özacar M., \& Ömürlü B., Decolorization of C.I. Reactive Red 124 Using the Electrocoagulation Method. Chem. Biochem. Eng. Q. 18 (4), pp. 391-401, 2004.

[8] Kobya M., Senturk E. \& Bayramoglu M., Treatment of poultry slaughterhouse wastewaters by electrocoagulation, Journal of Hazardous Materials 133(1-3), pp. 172-176. 2006.

[9] Marconato J.C., Bidoia E.D. \& Rocha-Filho R.C., Electrolytic treatment of wastewater from a fowl slaughterhouse using cast-iron electrodes, Bulletin of Electrochemistry 14 (6-7), pp. 228-230, 1998.

[10] Daneshvar N., Oladegaragoze A. \& Djafarzadeh N., Decolorization of basic dye solutions by electrocoagulation: An investigation of the effect of operational parameters. Journal of Hazardous Materials 129(1-3), pp. 116-122, 2006. 